\title{
AFTER SCHOOL ACTIVITY CORRELATED TO WINE PRODUCTION IN MICRO SCALE WITH ALCOHOLIC FERMENTATION OF STRAWBERRY JUICE. A HISTORICAL APPROACH OF WINE
}

\author{
Nikolaos Zikos ${ }^{1}$, Tasos Michailidis ${ }^{2}$ \\ ${ }^{1}$ Adjunct Lecturer / University of Athens - Chemistry Department, Teacher , \\ Zanneio Model Junior High School, Greece \\ ${ }^{2}$ Adjunct Lecturer / University of West Attica Teacher, \\ Zanneio Model Junior High School, Greece
}

DOI: 10.46609/IJSSER.2020.v05i10.026 URL: https://doi.org/10.46609/IJSSER.2020.v05i10.026

\begin{abstract}
During school year 2018-2019 we worked with our students (Experimental Junior High School in Athens) on an after school activity. The duration of the project was three months (November 2018 to January 2019). A group of 16 students (B and C class of Junior High School) took part in the project making investigation and experiments for 2 hours per week. The basic idea was first of all to make a historical reference in wine mentioning the role of Greece (in this step a philologist teacher took part in the whole project). Then the chemistry of fermentation reaction was taught to students and the benefits of wine consumption to human health. These topics are also included in chemistry school book of $\mathrm{C}$ class and in biology school book of A class of Junior High School. Then the experiment procedure took place in the school lab. The main aim of this article is to show the dynamic of afterschool activities in the school process.
\end{abstract}

Keywords: After school activities, Secondary education, winemaking, strawberry.

\section{After School Activities. A Pedagogical Approach}

An after school activity is any organized pedagogical program that students of a school unit can participate outside of the traditional school day. Some programs are run by a primary or a secondary school. The main purpose of these programs is students to gain extra knowledge, laboratory experience, leadership and social skills. Researchers have also shown that students who participate in such activities have improvement in their grades in the near future. These activities act as motivation for students. In Greek educational system after school activities are 


\section{International Journal of Social Science and Economic Research}

ISSN: $2455-8834$

Volume:05, Issue:10 "October 2020"

very common in model and experimental schools but there is the tense to expand in more schools in the future.

In European Union we observe also creation of similar type of schools (Model, Experimental and Schools of Excellence) in primary and secondary education. In Greek educational system the acceptance of students in experimental schools is taking place by lottery, while in model schools by examinations in mathematics and reading comprehension.

Model and experimental schools of primary and secondary education create a network of schools in order educational research, dissemination of good pedagogical practices and systematic evaluation of teachers and students to take place. These schools play an important role for the whole Greek educational system (Samara, 2015). In the future there is plan to create more Model or Experimental schools. It is remarkable that in after school activities can also take place students other schools.

In this specific article an after school activity is described. It took place in an experimental junior high school in the region of Piraeus. The activity involved the lessons of chemistry and history. 16 students and 2 teachers (chemist and philologist) participated. The basic idea was first of all to teach the history of winemaking and the correlation between wine consumption and human health. Then the chemistry of fermentation process was examined. In the final stage students made a fermentation experiment in micro scale in order to produce wine from strawberry juice.

\section{Wine consumption and human health}

The beneficial effect of moderate wine consumption to human health has been widely accepted (Renaud et al. 1999). Indeed, epidemiological studies showed a decrease in susceptibility of Low-Density Lipoprotein (LDL) to oxidation, which implies the contribution of wine consumption to the prevention of arteriosclerosis and other similar diseases( Cooper et al. 2004). This action can be explained on the basis of antioxidant activity of wine, attributed to many polyphenolic antioxidants, including flavonoids, such as flavonol and anthocyanins (Monagas et al. 2005).

Doctors suggest the consumption of one glass of wine (a quantity of about $100 \mathrm{ml}$ ) every day can contribute to human health and pretend from heart diseases. It is remarkable that red wines can contribute more compared to white wines due to higher concentration of antioxidants compounds.

\section{History of winemaking}




\section{International Journal of Social Science and Economic Research}

ISSN: $2455-8834$

Volume:05, Issue:10 "October 2020"

Wine has been a structural part of human nutrition since antiquity, which justifies the various cultural symbolic dimensions it has gained through history, as people and religions have considered it an integral part of their national, cultural and nutritional tradition. The process of viticulture is claimed to have begun during the agricultural revolution and the permanent settlement of populations around 5,000 BC. (Kontova, 2011).

The Egyptians were probably those who successfully developed the art of viticulture and winemaking, since amphoras dating back to 1600-1100 BC were found, indicating the origin, the wine harvest and the winemaker. However, other people, such as the Aryans (ancestors of the Indians), the Persians, the Semitic people and the Assyrians, have been argued that they have been among the first known wine producers. Characteristic is the case of the law adopted by King Hammurabi in $1700 \mathrm{BC}$ which set limits to the price of wine and determining when it should be consumed (only after the harvest).

After this short report, students were taught the specific role of Ancient Greece in wine making. The ancient Greeks, however, not only excelled in winemaking and monopolized the wine market for centuries but they were also influenced by it in all aspects of life, so it soon became a key element of their cultural identity. The most likely version is that they were taught about wine by the Phoenicians with whom they had developed commercial relations. In any case, the wine was directly associated with Dionysian worship and was loved by urban and rural populations alike as a means of escape from the problems of everyday life and as a way of reaching the state of ecstasy or creating a pleasant atmosphere, as can be seen in Plato Symposium (Zacharatos, 2007; ETVA, 1992).

In general, ancient Greeks have always supplemented their meals with wine, regarding those who drank anything other than wine barbarians, while they considered the consumption of waterfree wine ("akratosoinos") a barbarian habit. In particular, the wine of ancient Greeks was sweet and strong, but because it usually contained bits of grapes and vine leaves, they chose to drain and mix it with water and before drinking it they dropped a few drops on the floor as an offering to the gods. Indeed, this process of mixing it with water ("krasi") has given wine its most widespread Greek name, "krasi". The ratio was 1: 3, that is, a part of wine to three parts of water and there were special storage vessels, the craters. Widespread was also the consumption of wine with honey, as well as the use of herbs.

Ancient Greeks processed wine using methods similar to modern ones. They usually matured it in buried barrels that were sealed gypsum and resin, and they bottled them into shells or amphoras of clay, after they had tarnished them to stay dry. Characteristic of the importance of wine production and variety was the adoption of wine-related laws in various cities, such as 
International Journal of Social Science and Economic Research

ISSN: 2455-8834

Volume:05, Issue:10 "October 2020"

Thassos, which protected local production and set limits on competition and imports (Kontova, 2011; Flaceliere, 2007; Zacharatos, 2007).

With regard to the Greek area and the wine production in recent years, Greek viticulture was almost completely destroyed during the Greek Revolution of 1821 but immediately afterwards the crops were restored or increased, although a large part was planted with raisin-vine, a special variety of vine. In the following decades, however, the viticulture was strengthened by the annexation of Thessaly, Macedonia and Crete to the Greek state, and during that period the foundations of Greek oenology and controlled wine production were laid (Kontova, 2011; Zacharatos, 2007).

\section{The chemistry of fermentation reactions}

Alcoholic fermentation is an aerobic fermentation processes that begin with the sugar glucose. Through the process glucose is broken down into ethanol and carbon dioxide (Theodoropoulos et all, 2009). The whole process is taken part through yeasts which metabolizes sugar. As yeast continues to metabolize sugar, the accumulation of ethanol becomes toxic and eventually kills the cells. Most yeast can tolerate an alcohol concentration maximum of 10-15\% v/v before being killed. In wine making grape juice supplies yeast with the appropriate amount of glucose (AlbaLois \& Segal-Kischinevzky, 2010). The total chemical equation is the following:

$$
\mathrm{C}_{6} \mathrm{H}_{12} \mathrm{O}_{6} \longrightarrow 2 \mathrm{CH}_{3} \mathrm{CH}_{2} \mathrm{OH}+2 \mathrm{CO}_{2}
$$

We must mention that variation in wine quality is occurred, during the process of fermentation, when yeasts produces releases many aroma compounds from inactive precursors in grape juice. These compounds affect the sensory properties of the wine. (Swiegers \& Pretorius, 2007).

Strawberries

Strawberries are a common fruit in the Mediterranean diet. It includes major antioxidants compounds such as anthocyanin. These compounds have biological activity in human health (Giampieri et all, 2012). A 100g amount of strawberries contains approximately 33 kilocalories, is an excellent source of vitamin $\mathrm{C}$, a good source of manganese, and provides several other vitamins and dietary minerals in lesser amounts. In our project we took care of the total amount of sugars which is approximately of 4.9g. (USDA Food Composition Databases, 2017).

\section{Materials - Reagents}


The students worked in four groups $(4 \times 4)$. Each group worked independently and used the following materials and reagents:

- $1 \mathrm{~L}$ of strawberry juice. The strawberries were stored at refrigerator at $-4 \mathrm{o}$ C.

- $2 \mathrm{~g}$ of yeast

- $10 \mathrm{ml}$ of distilled water

- A Pasteur pipette (100 to $1000 \mu \mathrm{L})$

- Filter paper

- Volumetric cylinder $(10,100 \mathrm{ml})$

- Volumetric flask (500 ml)

- Plastic container (2 L)

- Glass funnel

\section{Experimental Procedure}

Our first thought was the formation of the groups to be random. The advantage of this is that is seen as fair by all involved. In our activity we wanted to make groups of four and we had sixteen students. We gave each student a number between one and four. Then we asked all numbers one to make one group, all the numbers two etc.

STEP 1. In the first week with the teacher of history students were informed about history of winemaking in Greece from ancient times until today, and benefits of wine consumption to human health. An discussion for Mediterranean diet also took place.

STEP 2. During the second week of the project all group of students prepared the strawberry juice. Using refrigerated strawberries (an amount of $8 \mathrm{kgs}$ ) and an electrical mixer $4 \mathrm{~L}$ of juice was prepared. The juice was stored in refrigerator $\left(4^{\circ} \mathrm{C}\right.$ temperature for 7 days $)$.

STEP 3. In the third week each group prepared the yeast solution. An amount of $2 \mathrm{~g}$ of yeast was diluted in $10 \mathrm{ml}$ of water using a volumetric cylinder. Then an amount of $500 \mathrm{ml}$ of strawberry juice was transferred to volumetric flask, the yeast solution was added and the total solution was homogenized. After ten minutes the $500 \mathrm{ml}$ solution was mixed with $500-\mathrm{ml}$ of strawberry juice in a plastic container. The container was not hermetically sealed in order carbon dioxide to be removed. The four plastic containers were stored for 40 days until completion of the fermentation reaction.

STEP 4. Then each $1 \mathrm{~L}$ solution was filtered in order to move away residues of the reaction and was transferred to a glass bottle. 


\section{International Journal of Social Science and Economic Research}

ISSN: $2455-8834$

Volume:05, Issue:10 "October 2020"

STEP 5. An amount of $100 \mathrm{ml}$ was used in order to estimate alcoholic degree through distillation. The alcoholic degree was about $7 \% \mathrm{v} / \mathrm{v}$ which is attributed to low sugar content of strawberry juice.

STEP 6. The content of each plastic bottle was transferred to 2 smaller glass bottles of $500 \mathrm{ml}$ which were sealed. The total production was 8 bottles. The bottles were stored at the school lab. In this part students discussed the process of maturation in winemaking.

STEP 7. The participant's students using the computer of school lab designed the label of wines.

STEP 8. The final product was presented to students and teachers of the whole school. The teacher had the opportunity to test the final product.

Conclusions

The whole educational activity shows the dynamic of afterschool activities. Our activity combined chemistry, history and biology. It is very important that we had cooperation between professors of different scientific fields and students of different classes. In our project students reached the conclusion that fermentation process can be applied also in grape and strawberry juice. Besides that these juices can be described as glucose solution in general. Students also discussed the possibility of making product with higher alcoholic degree (addition of glucose) or using juice of other fruits (e.g. apple, pear, pomegranate etc) in industry of fermentation.

It is important to mention that students realized the value of chemical experiments in micro scale. Due to high cost of reagents experiments (collated with chemistry, biology and physics) in the school lab are made with small quantities. Students reach the same conclusions because the laws and principles are the same.

In the future making vinegar using juice of fruits and bacteria instead of yeasts is planned to take place in the school lab. Also we plan in school years 2019-2020 and 2020-2021 to investigate the process of maturation to winemaking. For this purpose students and professors will measure antioxidant activity of wine samples. The measurements will hold at oenology laboratory of National and Kapodostrian University of Athens which students will visit. A research relevant to wine consumption and benefits of human health will take place in the region of Piraeus. We strongly believe that one of the great advantages of afterschool activities is the possible cooperation between schools and universities.

\section{References}

[1] Alba-Lois, Segal-Kischinevzky (2010). Yeast Fermentation and the Making of Beer and Wine. Nature Education . 
International Journal of Social Science and Economic Research

ISSN: 2455-8834

Volume:05, Issue:10 "October 2020"

[2] Cooper, K.A., Chopra, M., Thurnham, D.I. ( 2004 ). Wine polyphenols and promotion of cardiac health: a review. Nutrition Research Reviews.

[3] ETBA Cultural Technology Foundation(1992).History of Greek Wine: three days of work Santorini: ETVA.

[4] Flaceliere, R. (2007). The public and private life of the ancient Greeks, GerasimosVandoros. Athens: Papadimas.

[5] Giampieri, F., Tulipani, S., Alvarez-Suarez, J.M., Quiles, J.L., Mezzetti, B. \&Battino, M. (2012) The strawberry: composition, nutritional quality, and impact on human health..Nutrition.28 (1): 9-19.

[6] Kontova, D. (2011). The marketing of wines in Northern Greece, unpublished graduate thesis, Kavala Technical University, Department of Business Administration, Kavala. Retrieved 12-5-2017 at

http://digilib.teiemt.gr/jspui/bitstream/123456789/3146/1/0204\%CE\%9601\%CE\%960692.pdf.

[7] Liouni, M. (2009). Notes on chemistry and technology of wine and other alcoholic beverages. University of Athens.

[8] Monagas, M., Bartolome, B., Gomez- Cordoves, C. ( 2005 ). Updated knowledge about the presence of phenolic compounds in wine. Critical Reviews in Food Science and Nutrition.

[9] Renaud, S.C., Gueguen, R., Siest, G., Salomon, R. ( 1999 ). Wine, Beer, and Mortality in Middle-aged Men from Eastern France. Archives of Internal Medicine.

[10] Samara, A. (2015). Investigating The Transformations Of An Educational Institution In Greece: Model - Experimental Schools (MES).

[11] Theodoropoulos, P., Papathefoanous, P. \&Sideri F. (2009). Chemistry C Class Junior High School. Ministry of Education

[12] United States Department of Agriculture. Agricultural Research Service. USDA Food Composition Databases (2017). Retrieved 28-5-2017 at https://ndb.nal.usda.gov/ndb/search/list?qlookup=09316\&format=Full

[13] Zacharatos, Dionysios (2007). Wines OPAP and cooperative movement. The 
Cooperative of RobolaKefalonia. Diploma thesis, ATEI of Kalamata, Department of

Crop Production, Kalamata. Retrieved 14-5-2017 at

http://nestor.teipel.gr/xmlui/bitstream/handle/123456789/17395/STEG_FP_00449_Medium.pd $\mathrm{f}$ ? sequence $=1$.

\section{Photos}

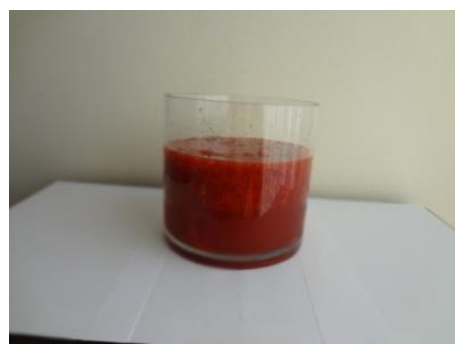

Photo 1: Initial Strawberry Juice

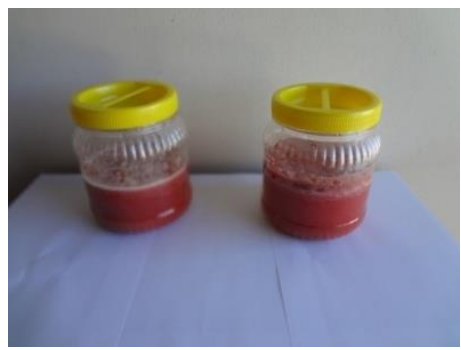

Photo 3. The process of alcoholic fermentation in plastic containers. (third week)

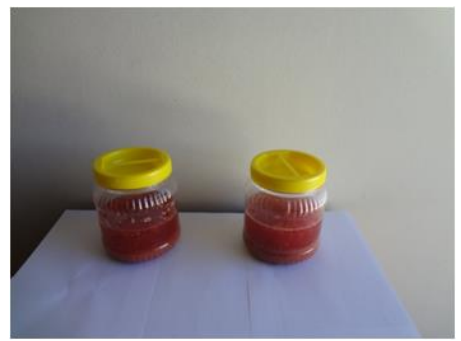

Photo 2. The process of alcoholic fermentation in plastic containers. (first week)

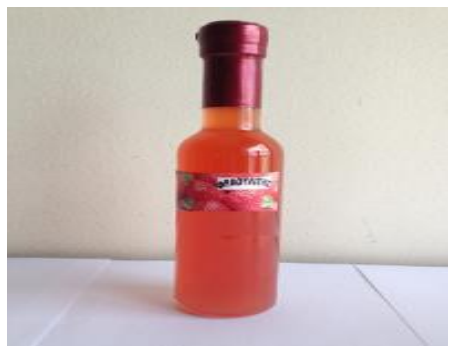

Photo 4. Final product 